\title{
Anatomy Teaching and Learning in Malaysia During the COVID-19 Pandemic
}

Received: 26-01-2021

Accepted: 27-02-2021

Online: 30-06-2021
Tg Fatimah Murniwati Tg Muda ${ }^{1,2}$, Madihah Rushaidhi', Choy Ker Woon ${ }^{4}$, Jagadeesh Dhamodharan ${ }^{5}$, Norzana Abdul Ghafar ${ }^{6}$, Wong Kah Hui ${ }^{7}$, Razif Abas ${ }^{8}$, Teoh Seong Lin ${ }^{6}$, Siti Nurma Hanim Hadie $^{9}$

${ }^{1}$ Faculty of Medicine, Universiti Sultan Zainal Abidin, Terengganu, MALAYSIA

${ }^{2}$ Department of Medical Education, School of Medical Sciences, Universiti Sains Malaysia, Kelantan, MALAYSIA

${ }^{3}$ Anatomy Working Group, Newcastle University Medicine Malaysia, Fohor, MALAYSIA

${ }^{4}$ Department of Anatomy, Faculty of Medicine, Universiti Teknologi MARA, Selangor, MALAYSIA

${ }^{5}$ Unit of Anatomy, Faculty of Medicine, AIMST University, Kedah, MALAYSIA

${ }^{6}$ Department of Anatomy, Faculty of Medicine, Universiti Kebangsaan Malaysia, Kuala Lumpur, MALAYSIA

${ }^{7}$ Department of Anatomy, Faculty of Medicine, Universiti Malaya, Kuala Lumpur, MALAYSIA

${ }^{8}$ Department of Human Anatomy, Faculty of Medicine and Health Sciences, Universiti Putra Malaysia, Selangor, MALAYSIA

${ }^{9}$ Department of Anatomy, School of Medical Sciences, Universiti Sains Malaysia, Kelantan, MALAYSIA

To cite this article: Tg Muda TFM, Rushaidhi M, Choy KW, Dhamodharan J, Abdul Ghafar N, Wong KH, Abas R, Teoh SL, Hadie SNH. Anatomy teaching and learning in Malaysia during the COVID-19 pandemic. Education in Medicine Journal. 2021;13(2):71-81. https://doi.org/10.21315/ eimj2021.13.2.6

To link to this article: https://doi.org/10.21315/eimj2021.13.2.6

\section{ABSTRACT}

The abrupt transition from face-to-face to online anatomy teaching amidst the COVID-19 pandemic has posed great challenges to anatomy lecturers in Malaysia, as they have had to adapt to new skills to prepare and deliver online classes. These online classes were delivered either synchronously via a web teleconferencing application or asynchronously through pre-recorded videos that were uploaded to the learning management system (LMS). The online delivery of anatomy practical classes has become a major concern among anatomy lecturers and students, especially in public institutions, as there is a lack of hands-on experience and social interaction. Nevertheless, some private medical schools have adapted well to both online lectures and practical classes, as they had been venturing towards online learning and virtual reality tools even before the pandemic commenced. The Malaysian Anatomical Association (MAA) webinar, "Transformation of Anatomy Education in Malaysia during COVID-19 Pandemic", discussed the issues related to lecturers' and students' receptivity to online anatomy classes. This study discusses the issues related to online anatomy teaching and learning (T\&L) and 
the actions taken by the university's governance and anatomy faculty members to resolve the issues discussed in the academic discourse.

Keywords: Anatomy teaching and learning, COVID-19 pandemic, Online lectures, Practical anatomy

Siti Nurma Hanim Hadie, Department of Anatomy, School of Medical Sciences, Universiti Sains Malaysia, 16150 Kubang Kerian, Kelantan, Malaysia

E-mail: snurma@usm.my

\section{INTRODUCTION}

The Malaysian authorities have been vigilant in managing a deadly infectious disease caused by the severe acute respiratory syndrome coronavirus 2 (SARS-CoV-2) - commonly known as COVID-19. The Movement Control Order (MCO) was first announced on 18 March 2020, and eventually, Malaysia was put under four phases of the MCO until 12 May 2020 (1). In response to the MCO, all educational institutions were prohibited from conducting physical teaching and learning (T\&L) activities. Instead, a comprehensive online T\&L approach was implemented to ensure the continuity of academic programmes. Subsequently, Conditional MCO (CMCO) and Recovery MCO (RMCO) were enforced from 13 May 2020 to 9 June 2020 and from 10 June 2020 to 31 December 2020, respectively. These enforcements allowed the conditional resumption of certain businesses to ease economic losses. During this period, the Ministry of Higher Education (MOHE) Malaysia announced that all T\&L activities must be executed online until 31 December 2020 (2). As of 26 January 2021, the authorities continued to adjust the country's movement restrictions order to curb the spread of COVID-19, whereby the MCO has been imposed across all states in Malaysia except Sarawak.

When the MCO was first enforced, all face-to-face T\&L activities were abruptly suspended. All higher institutions were closed and faculty members were asked to work from home. At first, students were allowed to stay on campus, but eventually arrangements were made by the MOHE and universities to send all the students home. Accordingly, the Malaysian Qualifications Agency (MQA) prepared several advisory notes as guidelines for higher institutions to conduct $\mathrm{T} \& \mathrm{~L}$ activities during and after the MCO (3-4). Based on these guidelines, university governance, especially those in the academic division had to vigorously plan and restructure academic schedules and activities in an attempt to maintain the accreditation of academic programmes. These contingency plans impacted a large spectrum of curriculum management, including the way classes were delivered, the selection of teaching tools to support remote learning, the professional development of the academic staff, the implementation of online assessment, counselling and psychological support, and the extra allocation of funding for curriculum management (5-7). Given the fluidity of the situation, several special task forces were developed to manage these areas to ensure the smooth running of the academic programmes.

Among the immediate actions taken by many universities was the purchase of a licence for a web telecast video conferencing application (i.e., Webex, Zoom and Microsoft Teams) for a formal teaching platform. In addition, the learning management system (LMS) platform that was usually used to support blended learning prior to COVID-19 was upgraded to cater to the broad array of online distance learning activities. The faculty members were trained in how to prepare and conduct synchronous and asynchronous teaching using these two platforms. Within that short enforcement period, the faculty members had no other option but to familiarise 
themselves with the online T\&L. It is concerning to think that nothing will likely return to the way it used to be, even when the current pandemic eventually subsides. However, the university's governance has been working hard to mitigate the problems related to online teaching, learning and assessment.

Likewise, the impact of the current pandemic on medical education has been unusual and far-reaching and presents unique challenges to medical schools (8). Since medicine and allied health sciences rely heavily on face-to-face teaching and interactions, and dynamic communications during patient-based and laboratory-based teachings, the impact of this pandemic is tremendous. Owing to the highly contagious nature of the COVID-19 virus, physical classes were limited and almost all T\&L aspects that involved close human contact were suspended as the number of positive and new cases in Malaysia spiked. Clinical and bedside teachings were impossible due to the exposure risks of COVID-19. At the time of writing, medical educators are still searching for the most effective method for developing students' skills, affective and professional behaviours as well as competencies, which seems to be minimally possible through online T\&L.

\section{ABRUPT TRANSITION FROM FACE- TO-FACE TO ONLINE ANATOMY T\&L}

Anatomy is one of the fundamental subjects for undergraduate medical students; hence, $\mathrm{T} \& \mathrm{~L}$ in anatomy is often conducted with a strong emphasis on its clinical application (9). Prior to the COVID-19 pandemic, many medical schools in Malaysia conducted anatomy teaching in a classical classroom setting, whereby $T \& L$ activities were mainly conducted face-toface (10). The theoretical knowledge was delivered mainly through lectures, either didactically or interactively, depending on the creativity of the lecturers and the availability of teaching facilities (10-12).
These lectures were usually followed by a peer or small group discussion in the form of tutorial classes, problem-based learning, case-based learning, team-based learning and fixed learning modules (13-14). Moreover, students were exposed to handson activities during the practical session, whereby they were expected to develop skills and affective competencies through various learning modalities. The practical sessions were often conducted using multimodal approaches, such as cadaveric dissection, self-exploration using anatomical plastic models and cadaveric specimens, and structured assessment-based practical and living models for surface anatomy teaching (15-18). While, for the histology practical, students were taught how to identify histological features of body tissues using light microscopy. Nevertheless, some medical schools had been trying to venture into online and digital anatomy teaching even before the COVID-19 pandemic, using gross anatomy software, augmented reality, mobile applications, gamification and virtual microscopy (19-23). However, these new teaching modalities have not been fully implemented in the curriculum, especially in public medical schools due to financial constraints and limited resources.

When the MCO was first announced on 18 March 2020, anatomy educators faced a significant challenge in teaching gross anatomy and histology to medical students, particularly because of the nature of this subject, which requires concurrent cognitive-based information delivery with hands-on activities either through cadaveric- or non-cadaveric-based modalities. Nonetheless, anatomy lecturers in Malaysia have been diligent in conducting T\&L activities via online platforms, either synchronously or asynchronously. Apparently, the shift from the previously established anatomy education system to a new education system has had different impacts on government and private medical schools. Most private institutions appear to have adapted better to online T\&L due to their competitive nature. In fact, some of 
the private medical institutions in Malaysia are branch campuses of world-renowned universities (i.e., Newcastle University Medicine Malaysia and Monash University Malaysia) and have partnerships with more than 20 renowned medical institutions (i.e., International Medical University). These private institutions had ventured into virtual anatomy T\&L even before the pandemic hit, which enabled them to adapt quickly to the changes and focus on other aspects of the curriculum. By contrast, most government institutions are still struggling to find effective ways to teach anatomy, especially when they must cater to larger student cohorts with multiple socioeconomic backgrounds.

\section{MAJOR CHALLENGES IN ANATOMY TEACHING DURING THE COVID-19 PANDEMIC}

It has been argued that the abrupt change in $\mathrm{T} \& \mathrm{~L}$ activities in anatomy has caused a toll on the psychological well-being of some faculty members as their teaching burden escalated. Although there is a scarcity of data to report such a claim, this issue was discussed in the MAA webinar conducted on 18 December 2020. Some university authorities have therefore been interviewing faculty members to identify any issues or problems they face when implementing online T\&L activities. One of the main results was the unreadiness of lecturers to implement online teaching because of their lack of experience and knowledge of online teaching. This challenge was overcome through a series of training sessions on online teaching provided by medical education personnel and continuous information technology support from the university. In fact, the Faculty of Medicine, Universiti Sultan Zainal Abidin (UniSZA) conducted a mock-synchronised online session for each lecturer to practice and troubleshoot their teaching before conducting actual online classes. These forms of support and reassurance managed to improve the readiness of anatomy lecturers to venture into online classes. From the training and mock sessions, the lecturers made certain improvements, such as adding quizzes and intra-lecture web activities during the lecture, to the design of online instruction to make it more interactive and engaging.

In the context of theory delivery, many anatomy lecturers felt that the efficiency of content delivery met their expectations when there was a suitable platform to deliver the lecture. Some lecturers found online teaching is convenient, as the lecture delivery can be conducted easily from home at their own pace, especially when it involves asynchronous recorded lectures. The tools available in the webcast teleconferencing application, such as the laser pointer and whiteboard, are effective in facilitating lecture delivery, which is comparable to the conventional delivery in the lecture hall. However, some lecturers perceived online teaching as challenging because they felt that the screen created a barrier to verbal and non-verbal communication. Not being able to see all the students on the computer screen affected their confidence level, as they were uncertain of how their students were reacting to their teachings. Perhaps students' body language (e.g., head nodding or frowning) provides hints to the lecturers about whether they understand the lectures. However, such body language is difficult to capture during online teaching, as an immediate response is usually lacking due to limitations in social interaction.

The biggest challenge lay in the online gross anatomy practical session. The majority of anatomy lecturers felt that the virtual practical session was less effective than conventional practical sessions using cadaveric specimens and other teaching tools. First, the lecturers felt that the 3D visualisation of anatomical structures was challenging in online sessions, making explanations about relations, surfaces and parts of organ structures difficult. Second, the visualisation of size was impossible, thus disabling the comparison of size and shape from one structure to another. 
Third, students were also unable to feel the texture of the anatomical structure, which is another important characteristic feature that differentiates structures from one another. For instance, allowing the students to feel the texture of an artery, a vein and a nerve will enable them to appreciate the existence of lumen, thickness and texture, which subsequently guides them to distinguish between these structures. Henceforth, the majority of the anatomy lecturers felt that hands-on sessions were still the best approach for the gross anatomy practical.

Some medical schools in Malaysia have taken active measures to overcome the issues surrounding the anatomy practical. During the first RMCO period, the National Security Council made an announcement on 29 June 2020 that allowed certain categories of students to return to campus between July 2020 and October 2020 (24). These categories included postgraduate students in research mode programmes and undergraduate students who required practical training and special equipment for their learning. Taking these into consideration, the Asian Institute of Medicine, Science and Technology (AIMST) University had allowed their pre-clinical year medical students to return to the campus and resume their practical learning with strict standard operating procedures (SOPs) controlled by the AISMT COVID Special Task Management Force. The Anatomy Unit of AIMST University meticulously planned the practical sessions so that proper social distancing and all other necessary SOPs were strictly enforced within the anatomy dissection hall and histology lab. Active measures were undertaken to reduce the number of students allocated at each dissection table from 25 to 10 students. Each dissection room consisted of only one dissection table with 10 students and one academic staff member, which allowed them to maintain social distancing. Nevertheless, the design of this practical method requires the lecturers to repeat the same practical session three times, which imposes a considerable burden on them.
In different instances, some public medical schools that are more cautious about bringing the students back to campus decided to purchase anatomy software to replace the face-to-face anatomy practical session. For instance, Universiti Sains Malaysia (USM) purchased applicationbased complete anatomy software that can cater to the learning of 600 students at one time. The main aim of purchasing the software was to temporarily replace the face-to-face practical session during the COVID-19 pandemic. Even so, this form of a practical session would never be able to replace the experience of learning through cadaveric dissection, cadaveric specimens and living anatomy. Moreover, the virtual learning software is expensive and many institutions could not afford to buy it.

\section{STUDENTS' ACCEPTANCE OF ONLINE ANATOMY TEACHING}

The students' acceptance of online anatomy learning varied across individuals and institutions, as multiple factors influenced their perceptions of online T\&L. This issue was also discussed in the aforementioned MAA webinar, in which it was agreed that students' acceptance is a multifactorial construct. Among the major factors that resulted in students having unfavourable attitudes towards online learning are their socioeconomic status, family support, poor internet connection and differences in the time zone. Many students from low socioeconomic backgrounds could not afford to buy a laptop or tablet for learning, which they usually had the privilege of using in the cybercafe of the library when they were on campus. Most of the time, the students who did have one needed to share the device with their siblings, who were also required to learn through an online platform. Some students had to do house chores or extra jobs to help their parents, who were working and were in the midst of an economic crisis. These factors imposed an extra burden on the students, as they could not concentrate 
on their classes as well as they could when they were on campus. The students from the lower socio-economic background also had problems with low internet bandwidth, as they could not afford to buy a wider internet connection bandwidth, and they had to share the internet connection with their siblings. This limited internet connection could not cater to continuous online T\&L. Some students who lived in remote areas had extremely limited internet connections. In this case, it was almost impossible to learn from online lectures from their home, and they had to find a suitable location outside their residential area to get a good internet connection. Some institutions, such as Universiti Kebangsaan Malaysia (UKM) and USM, have international medical students who have been residing in their own countries since the COVID-19 pandemic took hold. The difference in the time zones between these countries has prevented students from attending scheduled synchronous classes. All of these factors, despite being anecdotal, are real problems reported by the students. Nevertheless, some students have been able to adapt well to online T\&L, especially when lecturers are innovative in finding efficient ways to facilitate their learning.

To understand students' perspectives on online T\&L and identify their learning needs, many medical schools have collected regular feedback. Among their major concerns about the quality of online anatomy, T\&L is about the practical sessions. Many of the students expressed their concerns about being unable to perform hands-on activities during the practical session. As mentioned in the previous section, many medical schools have taken proactive measures to address this problem, even though these methods cannot replace the hands-on learning experience. Some universities have also been vigilant in providing financial aid for students who come from low socio-economic backgrounds. For instance, UniSZA has provided computer grants to students worth RM1,500 and unlimited internet bandwidth or financial support amounting RM120 per month for four months to students in need. Several safeguard measures were also undertaken to address the issues of students who could not attend online classes for various reasons. Among these is optimising the use of an LMS, whereby the lecturers could upload the recorded synchronous lecture or learning material into the e-learning portal. This method allows students to access the material at their convenience. The use of WhatsApp and Telegram applications is also beneficial in conducting personalised discussions, as they require little internet bandwidth. In fact, lecturers at USM had experience sending each PowerPoint slide that was captured as a picture through the WhatsApp application with recorded audio for each slide. It has helped the students tremendously, especially those in remote areas with low internet connections.

\section{MULTIMODAL ANATOMY TEACHING APPROACHES AMIDST COVID-19}

The COVID-19 pandemic has shifted anatomy teachings to online delivery and has sparked innovative ways to give students the optimum learning experience. Most online lectures are delivered synchronously; this is comparable to a face-to-face learning environment, which enables students to interact with the lecturers during the sessions. The lecturers are encouraged to record their live lectures and upload them to the respective university LMS platform so that they can be accessed by students who might have missed the lectures. Likewise, a pre-recorded lecture is a good alternative to a synchronous lecture. To address the issues of students with computer data storage problems, recorded lectures were also uploaded on YouTube. Doing so enabled the students to watch the lectures using the link instead of downloading the lecture, thus, reducing the amount of internet data and data storage required. 
In addition, the anatomy lecturers aimed to make the delivery of the lectures engaging by using game-based online applications, such as Kahoot, Quizzes and Socrative, in an effort to gain students' attention, collaboration and interaction. The questions were designed by anatomy lecturers and educationists in a way that balances academic subjects with the strategies, rules and social aspects of gamification. Moreover, game-based learning also allowed the lecturers to objectively evaluate the outcome and effectiveness of online distance learning on a particular topic. In addition to engaging lectures, some universities provided a pre-lecture activity that was uploaded to the LMS platform two to three days prior to each anatomy lecture. The concept of providing pre-lecture activities is similar to blended learning, which requires students to prepare beforehand so that they can integrate their prior knowledge with the newly received information in the lecture (25). Nevertheless, the pre-lecture activities should be designed to be as simple as possible and must not impose an extra burden on the student. The most frequently applied pre-lecture activity is a short video viewing, guided by a list of questions that requires the students to find answers to the questions on the video.

As an alternative to hands-on practical anatomy, the $3 \mathrm{D}$ anatomical software, which provides interactive features, including digital dissections has become more popular amongst the medical institutions. Most institutions prepared the students for the virtual anatomy practical with pre-recorded videos that served as the pre-laboratory session. Students were asked to prepare before coming to the virtual lab sessions by completing worksheets or anatomy handouts provided. Owing to limited access to the campus and learning resources, e-books and $3 \mathrm{D}$ anatomy software, which can be downloaded to the students' personal devices were made available. The virtual anatomy laboratory session was normally conducted as a live online session using various webcast teleconferencing platforms, whereby the instructor used virtual cadaveric materials or models to dissect or demonstrate the various structures and functions to the students. The session normally ended with a Q\&A session or attempt quizzes.

Universities such as Newcastle University Medicine Malaysia and International Medical University also used the advanced feature of Zoom and Webex platform, namely the Break-Out Rooms application, which allows concurrent small group discussion among students within a large group cohort. The anatomy working group at Newcastle University Medicine Malaysia utilised this feature to create small groups within the virtual anatomy lab sessions. These sessions imitate the similar settings of small group activities during the face-to-face anatomy lab teachings. The group started the online anatomy lab teachings with pre-recorded video and tutorial links to aid students with their self-study and preparation before attending the live anatomy lab session. The online resources such as e-books and $3 \mathrm{D}$ anatomy software (Complete Anatomy Apps) were made available for the students. After the anatomy lab introduction, the students were directed to their small group discussions, where they discussed a task. Another great feature of Zoom, called the "whiteboard", is a virtual whiteboard that can be used within the small group discussion for the students to draw images, write notes or insert pictures and labels. If the students were having difficulties during their small group discussion, they could virtually raise their hands and attract the attention of the lecturers or laboratory demonstrators who hosted the sessions. This method is comparable to the face-toface practical session, where students sat in their small groups to study and discuss the anatomical models with their peers and get assistance from the lecturers or laboratory demonstrators when needed. Students were automatically removed from the "breakout rooms" once the time ended and would re-join the rest of the classroom. 
A representative from each breakout room was asked to present their discussions or to summarise the session. Virtual anatomy quizzes were also given to enhance the students' understandings. Table 1 summarises the anatomy T\&L activities during the pre-COVID-19 and COVID-19 pandemic eras.

\section{CONCLUSION}

The COVID-19 pandemic has markedly changed the T\&L modalities from conventional face-to-face to online teaching. Despite the challenges faced by the lecturers in ensuring that the quality of education is not jeopardised, the lecturers gained new competencies in preparing and delivering online materials - something which might not have happened during the preCOVID-19 era. The lecturers have become more creative and innovative in their teaching with the support of their respective universities in adapting to a new norm in the teaching methods. Nevertheless, it is worth highlighting that the present online anatomy T\&L activities only covered the cognitive part of the knowledge. It is debatable whether the current anatomy $\mathrm{T} \& \mathrm{~L}$ could ensure the attainment of skills and affective learning outcomes, as these competencies are mainly achieved through the face-to-face sessions. Hence, it is advisable to revisit the anatomy $\mathrm{T} \& \mathrm{~L}$ activities in the post-COVID era to address the attainment of skills and affective learning competencies, even though students are already in their clinical years.

Table 1: The anatomy T\&L activities during the pre-COVID-19 and COVID-19 pandemic era

\begin{tabular}{|c|c|c|}
\hline T\&L modality & Pre-COVID-19 & During COVID-19 \\
\hline Lecture & $\begin{array}{l}\text { Face-to-face session in lecture hall. } \\
\text { Blended learning and flipped } \\
\text { classroom. }\end{array}$ & $\begin{array}{l}\text { Online synchronous lecture. } \\
\text { Pre-recorded asynchronous lecture. } \\
\text { Interactive online lecture with } \\
\text { game-based learning. } \\
\text { Blended learning with pre-lecture } \\
\text { activities. }\end{array}$ \\
\hline $\begin{array}{l}\text { Gross anatomy } \\
\text { practical }\end{array}$ & $\begin{array}{l}\text { Cadaveric dissection. } \\
\text { Self-exploration using cadaveric } \\
\text { specimens and anatomy models. } \\
\text { Living models for surface anatomy } \\
\text { teaching. } \\
\text { Structured assessment-based practical. } \\
\text { Learning using 3D and augmented } \\
\text { reality anatomy software. }\end{array}$ & $\begin{array}{l}\text { Learning using 3D and augmented } \\
\text { reality anatomy software. } \\
\text { Synchronous online demonstration } \\
\text { and discussion. } \\
\text { Pre-recorded demonstration video. } \\
\text { Small group discussion using the } \\
\text { 'Break-out Room' feature of } \\
\text { Zoom and Webex platform. }\end{array}$ \\
\hline Histology practical & $\begin{array}{l}\text { Hands-on session using light } \\
\text { microscopy. } \\
\text { Virtual slides demonstration and } \\
\text { discussion. }\end{array}$ & $\begin{array}{l}\text { Virtual slides demonstration and } \\
\text { discussions. }\end{array}$ \\
\hline $\begin{array}{l}\text { Tutorial and } \\
\text { discussion }\end{array}$ & $\begin{array}{l}\text { Small group discussion. } \\
\text { Fixed learning module. } \\
\text { Problem-based learning. } \\
\text { Team-based learning. }\end{array}$ & $\begin{array}{l}\text { Small group discussion using the } \\
\text { 'Break-out Room' feature of } \\
\text { Zoom and Webex platform. }\end{array}$ \\
\hline
\end{tabular}




\section{ACKNOWLEDGEMENTS}

This study was supported by the National Grant (The Fundamental Research Grant Scheme, Grant number: 203. PPSP.6171273). The principal investigator is from Universiti Sains Malaysia.

\section{REFERENCES}

1. Abdullah JM, Ismail WFNW, Mohamad I, Ab Razak A, Harun A, Musa KI, et al. A critical appraisal of COVID-19 in Malaysia and beyond. Malays J Med Sci. 2020;27(2):1-9. https://doi.org/10.21315/ mjms2020.27.6.1

2. Mohamad Nasri $\mathrm{N}$, Husnin $\mathrm{H}$, Mahmud SND, Halim L. Mitigating the COVID-19 pandemic: a snapshot from Malaysia into the coping strategies for pre-service teachers' education. J Educ Teach. 2020;1-8. https://doi.org/10.1080/02607476.2020.180 2582

3. Malaysian Qualification Agency [Internet]. Malaysia: MQA. 2020 May 29 [cited 2021 January 2]. Advisory Note No. 4/2020: panduan pengendalian program pendidikan tinggi semasa dan pasca perintah kawalan pergerakan. Available from: https://www. mqa.gov.my/pv4/document/advisoryNotes/ Advisory Note No. 4-2020 (Versi BM) Panduan Pengendalian Program.pdf

4. Malaysian Qualification Agency [Internet]. Panduan pengendalian program pendidikan tinggi semasa dan pasca perintah kawalan pergerakan Covid-19. 2020 March 29 [cited 2021 January 2]. Available from: https://www.mqa.gov.my/pv4/document/ advisoryNotes/Advisory Note No. 1 2020 - Panduan Pengendalian Prog PPT 20200329.pdf
5. Center of Academic Excellence [Internet]. Malaysia: CDAE, USM. 2020 [cited 2021 January 2]. USM guidelines for teaching and learning plan for contingencies COVID-19. Available from: https:// www.usm.my/images/covid 19/USM TLGuidelines_for_COVID19.pdf

6. Universiti Malaya [Internet]. Garis panduan pengendalian dan pelaksanaan pengajaran \& pembelajaran semasa pandemik COVID-19. 2020 [cited 2020 January 4]. Available from: https://umacademic.um.edu.my/img/files/ Covid $\% 20$ News/Garis $\% 20$ Panduan $\% 20$ PdP\%20Online/Garis\%20Panduan \% 20 Pengajaran\%20Dan\%20Pembelajaran $\% 20$ $\mathrm{Dalam} \% 20 \mathrm{Talian} \% 20 \mathrm{Sem}$ as a $\% 20$ Pandemik\%20COVID-19.pdf

7. Universiti Teknologi MARA. Pekeliling Naib Canselor Bilangan 08 Tahun 2020 - Pekeliling Pelaksanaan Penyampaian dan Penilaian Pembelajaran Termasuk Kurikulum Berikutan Penularan Wabak COVID-19 dan Perintah Kawalan Pergerakan. 2020 [cited 2021 January 2]. https://kedah.uitm.edu.my/images/circullar/ Pekeliling_Naib_Canselor_Bilangan_08_ Tahun_2020.pdf

8. Yusoff MSB, Hadie SNH, Mohamad I, Draman N, Al-Aarifin IM, Rahman WFWA, et al. Sustainable medical teaching and learning during the COVID-19 pandemic: surviving the new normal. Malays $\mathrm{J}$ Med Sci. 2020;27(3):137-42. https://doi.org/10 $.21315 / \mathrm{mjms} 2020.27 .3 .14$

9. Ganguly PK. Teaching and learning of anatomy in the 21st century: direction and the strategies. Open Med Educ J. 2010;3(1):5-10.

10. Nasir A, Salam A. A study of anatomy teaching in Universiti Sains Malaysia. Malays J Med Sci. 2006;13(Supp.1):19. 
11. Hadie SNH, Abdul Manan@Sulong H, Hassan A, Mohd Ismail ZI, Talip S, Abdul Rahim AF. Creating an engaging and stimulating anatomy lecture environment using the cognitive load theory-based lecture model: students' experiences. J Taibah Univ Med Sci. 2018;13(2):162-72. https://doi .org/10.1016/j.jtumed.2017.11.001

12. Kibria G. Anatomy teaching and learning strategies in National Defence University of Malaysia (NDUM): team based learning and museum specimen demonstration title. In: Tg Muda TFM, Hadie SNH (eds). Malaysian Anatomical Association Education Symposium. Kuala Terengganu: Malaysian Anatomical Association; 2018. p. 36.

13. Latiff AA, Kamarzaman S, Manan N, Rampal K, Muniandy B. Students' perception on anatomy education in Cyberjaya University College of Medical Sciences. Journal of the Anatomical Society of India. 2019;68(2):163-73. https://doi.org/ 10.4103/JASI.JASI_46_19

14. Shamsuddin SA, Kasim F, Mohammad JAM, Yusoff MSB, Hadie SNH. The outcomes of team-based learning on test performance, cognitive engagement and motivation in preclinical anatomy practical classes. Mal J Med Health Sci. 2021;17(2):18-27.

15. Salehuddin AR. Case-based and enquirybased approaches in teaching human anatomy. In: Tg Muda TFM, Hadie SNH (eds). Malaysian Anatomical Association Education Symposium. Kuala Terengganu: Malaysian Anatomical Association; 2018. p. 17.

16. Ikhwan MS, Asari MA, Mohd Ismail ZI, Kasim F, Yusoff NA, Hadie SNH. No students' evaluation on the OSCE-based gross anatomy practical session in School of Medical Sciences, Universiti Sains Malaysia Title. In: Tg Muda TFM, Hadie SNH (eds). Malaysian Anatomical Association Education Symposium. Kuala Terengganu: Malaysian Anatomical Association; 2018. p. 23.
17. Rushaidhi M, Mayo RM. Enhancing knowledge of anterolateral abdominal walls musculature in medical students using interactive coloured adhesive tape and skeleton model activity. In: Tg Muda TFM, Hadie SNH (eds). Malaysian Anatomical Association Education Symposium. Kuala Terengganu: Malaysian Anatomical Association; 2018. p. 32.

18. Latiff AA, Kamarzaman SK. The effectiveness of AnatoVAK practical package among year 1 medical students in musculoskeletal system. In: Tg Muda TFM, Hadie SNH (eds). Malaysian Anatomical Association Education Symposium. Kuala Terengganu: Malaysian Anatomical Association; 2018. p. 35.

19. Simok AA, Hadie SNH, Abdul Manan H, Yusoff MSB, Noor NFM, Asari MA, et al. The impact of virtual microscopy on medical students' intrinsic motivation. Education in Medicine Journal. 2019;11(4):47-59. https://doi.org/10.21315/eimj2019.11.4.5

20. Jusoh AR. Educreative 4.0. In: Tg Muda TFM, Hadie SNH (eds). Malaysian Anatomical Association Education Symposium. Kuala Terengganu: Malaysian Anatomical Association; 2018. p. 38.

21. Singh A, Mosameh MA. 3-Dimensional augmented reality mobile application in learning human anatomy: a pilot study. In: Tg Muda TFM, Hadie SNH (eds). Malaysian Anatomical Association Education Symposium. Kuala Terengganu: Malaysian Anatomical Association; 2018. p. 22.

22. Salehuddin AR. "1StopAnatomy" mobile application. In: Tg Muda TFM, Hadie SNH (eds). Malaysian Anatomical Association Education Symposium. Kuala Terengganu: Malaysian Anatomical Association; 2018. p. 26. 
23. Adrillana CPC, Rushaidhi M, Fernandez DRA, Mayo RM, Cruz ALC. Complete anatomy application: a qualitative study on the impact of learning from the students' perspective. In: Tg Muda TFM, Hadie SNH (eds). Malaysian Anatomical Association Education Symposium. Kuala Terengganu: Malaysian Anatomical Association; 2018. p. 31.

24. Ministry of Higher Education [Internet]. Standard operating procedure during and after COVID-19 pandemic movement control order - managing students back to campus movement. 2020 July [cited 2021 January 4]. Available from: https://umacademic.um.edu.my/img/ files/SOP KEMASUKAN PELAJAR ANTARABANGSA - ENG (1).pdf
25. Hadie SNH, Simok AA, Shamsuddin SA, Mohammad JA. Determining the impact of pre-lecture educational video on comprehension of a difficult gross anatomy lecture. J Taibah Univ Med Sci. 2019;14(4):395-401. https://doi.org/10 $.1016 /$ j.jtumed.2019.06.008 